\title{
EU Refugee Crisis: A Stumbling Block to the Process of European Integration?
}

\author{
DIONYSIOS STIVAS \\ Hong Kong Baptist University \\ stivasd@life.hkbu.edu.hk
}

\begin{abstract}
Currently, the European Union (EU) is dealing with an unprecedented refugee crisis which has been blamed for bringing the process of the EU integration to an impasse. By applying theories of European (dis)integration, this paper assesses the extent to which the current refugee crisis constitutes an impediment to the future of the European Union. This paper's analysis is constructed around two hypotheses: (1) the refugee crisis triggered Brexit and the failure of the EU's relocation scheme, symptoms of the EU's disintegration; (2) the refugee crisis has a dual potential: to simultaneously promote the deeper integration and the disintegration of the EU. To test these hypotheses, this paper examines if and how the refugee crisis is related to Brexit and whether the rebellious reaction of certain EU member states to the implementation of the EU relocation scheme is a sign of reversal in the process of EU integration.
\end{abstract}

Keywords: Brexit, European Disintegration, European Integration, European Union, Refugee Crisis, Relocation Scheme

\section{Introduction}

On March 2017, Jean-Claude Juncker, the President of the European Commission, presented his visions on the future of Europe and enumerated the challenges that the European Union (EU) encounters: the emergence of new Global Powers, Brexit, terrorist attacks, financial crisis, and "the largest refugee crisis since the Second World War" (European Commission, COM(2017) 2025). Although Juncker perceived these challenges as opportunities for the "adaptation and evolvement" of the EU (European Commission, $\operatorname{COM}(2017)$ 2025), other commentators consider these challenges as symptoms of the EU's dissolution (Bosoni, 2016; David, 2016; Warren, 2017). An assesment of the 'crises' that the EU has dealt with supports Junker's optimism. The collapse of the European Defence Community in 1954, the French rejections of the two UK bids in the 1960s, the empty-chair crisis in 1965, the crisis about the British contribution to the EU budget throughout 1989 to 1985, the almost abolition of the European Monetary System in 1992-1993, the failed referenda in Denmark, Ireland, France and the Netherlands, and more recently, the Eurozone crisis did not derail the process of European integration. The expansion of the EU's integrative policies followed most of those crises. However, the refugee crisis ${ }^{1}$ the EU is currently dealing

\footnotetext{
${ }^{1}$ For the purposes of this paper the term 'refugee crisis' is utilised. The term is often observed in official and unofficial EU documents. Although not everyone who seeks refuge in the European Union fulfils the conditions of being designated as a refugee, the EU Institutions refer to the recent migration outbreak as 'refugee crises in their official documents.
} 
with is unique. The consequences of this crisis are considered as impediments to the EU integration process. First, prominent politicians assume that the refugee crisis provoked Brexit, an allegedly detrimental development for the process of EU integration. Second, the failure of most EU member states to implement the 'EU-made' relocation scheme is considered as an indication of decline in the actual capacity of the EU to make and implement decisions, a symptom of EU disintegration.

The assessment of the extent to which these developments relate to the ongoing refugee crisis and to the (dis)integration of the EU is absent in the current literature. Although some scholars suggest the existence of a link between the 'intra-EU' immigration and Brexit, none have assessed the effects of the refugee crisis on Brexit. The repercussions of the relocation scheme's failure on the European integration ${ }^{2}$ process also lacks examination by scholars. To investigate the relationship between the refugee crises, Brexit, the relocation scheme's failure and the (dis)integration of the EU this paper tests the following hypotheses:

$\mathrm{H}_{1}$ : the refugee crisis, which triggered Brexit and the failure of the EU's relocation scheme are symptoms of the EU's disintegration.

$\mathrm{H}_{2}$ : the refugee crisis has a dual potential: to simultaneously promote the deeper integration and the disintegration of the EU.

To test these hypotheses, this paper examines empirical evidence within a causal framework $^{3}$ tracking down a causal link between the refugee crisis and the disintegration ${ }^{4}$ of the European Union. To do so, it assesses case studies and employs critical discourse $e^{5}$ and content analysis as illustrated in Figure 1.

The case studies to be assessed are Brexit and the EU relocation scheme's failure. The required data for testing whether the refugee crisis contributed to Brexit is collected from official public opinion surveys, political and media archival documents. It is examined through the performance of discourse analysis on the political and media framing of Brexit-refugee crisis nexus and content analysis on the public surveys' findings. To investigate the EU relocation scheme's failure and its contribution to the disintegration of the EU, this paper takes into consideration statements made by the leaders of Hungary and Slovakia. A landmark judgement of the Court of Justice of the $\mathrm{EU}$ (CJEU) on a case related to the relocation scheme is also taken into account.

The next paragraphs outline the theoretical framework of (dis)integration. Following on the paper will examine the extent to which the refugee crisis has triggered Brexit. The consequences of the 'annoyance' of some EU member states with the EU relocation

\footnotetext{
${ }^{2}$ There are several processes of European integration apart from the European Union project. The Council of Europe, EEA and EFTA constitute some of them. However, for the purposes of this paper, European integration refers only to the European Union and to the processes of enlargement of this peculiar international organization and the gradual attribution of a large array of competences to Brussels from the European Union member states.

${ }^{3}$ Cause-effect relationships are characterized by the regularity of determinism: if we assume that certain observed regularities, when event or phenomenon of type A takes place it is assumed logically that phenomenon of type B will follow.

${ }^{4}$ Kelemen (2007, pp. 61- 65) distinguishes between five EU disintegration scenarios: dissolution, limited secession, atrophy, the growth of variable geometry, and civil war.

${ }^{5}$ Discourse analysis can be understood as a scientific approach (a manner deconstructive reading) to analyzing (written, vocal or sign) language use or any relevant communicative event.
} 
scheme and the decisions of the CJEU for the viability of the EU's integration project are investigated. The responses to these questions provide answers to the research question, support the analysis and 'feed' the concluding remarks of this paper.

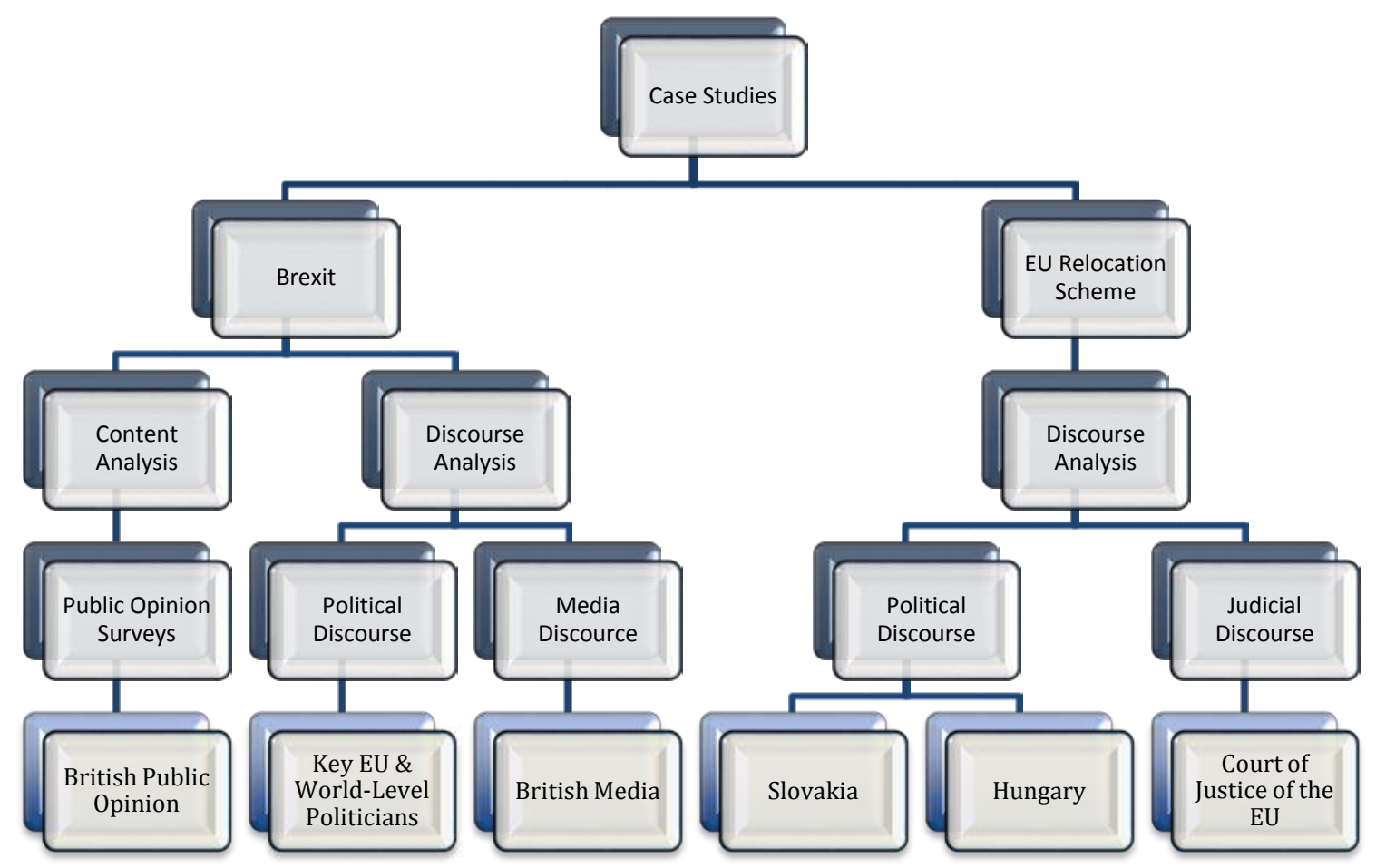

Source: Author's own analytical framework.

Figure 1. Methodological Approach

\section{(Dis)Integration Theorised}

Although many scholars have studied the process of European integration (Deutsch 1969; Etzioni, 2001; Franck, 1968; Hass, 1968; Mearsheimer, 1990; Riker, 1975), only a few have investigated the disintegration potential of the EU. Ernst Haas, one of the first scholars who examined the phenomenon of European integration, described it as "the process whereby political actors in several distinct national settings are persuaded to shift their loyalties, expectations and political activities towards a new centre, whose institutions possess or demand jurisdiction over pre-existing national states" (1968, p. 16). Recently, the UK voters decided to shift their own and their country's loyalties, expectations and political activities away from the EU. In addition, the EU institutions recently failed to persuade the EU member states to implement the relocation scheme. The failure of the EU relocation scheme indicates a decline in the European Commission's and the CJEU's persuasive power. Most likely, if one applies Haas' integration criteria in reverse, one would assume that the $\mathrm{EU}$ is beginning to disintegrate. The jurisdiction of the EU institutions seems slightly eroded and one of the core member states has shifted its loyalties, expectations and political activities away from the centre. Given the absence of an 'original' disintegration analytical framework in the current literature, by 'reversing' the existing integration theories (as with Haas' theory) one could raise the question as to whether the EU could disintegrate in the aftermath of Brexit and failure of the EU relocation scheme.

\section{Promoting the Interests of the Superpowers}


The advocates of neo-realism predicted that the end of the Cold War would also signal the 'end' of the EU because the departure of the superpowers would make Europe multipolar, imbalanced and unstable (Mearsheimer, 1990). Following the departure of the superpowers not only did the EU not disintegrate, but it managed to further integrate and to become a 'superpower' itself, at least in economic terms. Neo-realist's assumptions seem to be analytically too limited since they assume the world is made only of states, a fact that makes their expectations about the EU biased towards disintegration (Vollaard, 2008, p. 5). The bias towards disintegration did not allow the neo-realists to foresee the potential of the EU's deeper and wider integration.

\section{Taxation, Army and 'Federal' Loyalty}

From another perspective, scholars who study how federations emerge and decline assume that the survival of a federal system depends on the centralization of tax and armies, the guarantees of the partial autonomy of the constituent units, the growing federal loyalty of the individual citizens and the uniting force of cross-level organised political parties (Riker, 1975, p. 136). The EU is not a federation and perhaps will never become one. Although the EU combines elements of federations, states and international organisations, one of these elements is absent from the EU: the formation of an EU army. However, it would not come as a surprise if the EU member states, driven by the political instability surrounding Europe, considered creating one to better protect their common EU borders. The departure of the UK, an EU member state that was in favour of wider but against deeper integration, could increase the likelihood of defence integration and in the long run, the EU's military capabilities (Evans et al, no date).

\section{Convergence of Interests}

A useful tool for better understanding and explaining the (dis)integration of the EU is the use of classical intergovernmentalism's analytical framework. It assumes integration as contingent on the degree of the key member states' convergence of interests and preferences and shaped by the requirements of domestic politics (Webber, 2014, p. 344). It considers the evolution and degree of convergence of the French, German and British interests and the major upsurge of 'anti-European' domestic political attitudes as determinants of the EU's future (Webber, 2014, p. 341). Given the UK's departure from the EU, the Franco-German sharing of common views about the future of the EU is essential for the EU's further integration. Currently, France and Germany seem to endorse the manner by which the EU is handling the refugee crisis. It is likely that a potential disagreement on this matter would cause a major breakdown in the Franco-German relations. If such a breakdown were to occur, combined with the apparent sharp rise of Euroscepticism across Europe, classical intergovernmentalists would argue that the 'end' of the EU is approaching. 


\section{Spillover and Spill-Back}

For neo-functionalists, the key determinant of EU integration is the spillover effect of economic integration which produced the harmonisation of activities alongside that of economic policies of the EU member states. The process of regional integration depends on the realisation of mutual gains from cooperation in policy areas characterised by high levels of functional interdependence (Schmitter and Lefkofridi, 2016, p. 3). However, armed with an optimistic perspective of neo-functionalism on European integration, regional integration equally failed to capture the possibility of disintegration. Schmitter (2000) argued that a comprehensive theory of European integration should also accommodate the potential of EU disintegration. Hence the neo-functionalists' concept of spill-back which refers to "a situation in which there is a withdrawal from a set of specific obligations, rules are no longer regularly enforced or obeyed, and the scope of Community action and its institutional capacities decrease" (Lindberg and Scheingold, 1970, p. 137; Schmitter and Lefkofridi, 2016, p. 3). Because of the spill-backs, common policies are expected to suffer as a result of the growing number and heterogeneity of member states and their interests, leading to stagnation and political deadlock. Spill-backs block institutional reforms and cause partial disintegration of the EU. The failure of the EU's relocation scheme has the appearance of such a spill-back situation. The fact that several EU member states withdrew (partially) from their obligations to relocate the refugees from Greece and Italy reveals that they are openly disobeying EU rules. That inability of the EU to enforce its 'EUmade' rules indicates a decrease in the EU's scope of action and a decline in the capacities of its institutions. All these are symptoms of the EU's partial disintegration according to the neo-functionalists' spill-back narrative.

\section{Trans-national Activities}

From another perspective, transactionalism emphasises the importance of transactions, communications, social exchange, compatibility of values, commonality in identity and loyalty, and the joint rewards for the participant states for the longevity of the European integration project (Deutsch, 1969). Sandholtz and Stone Sweet (1998, p. 4) suggest that the expansion of trans-national activity is a "catalyst of European integration". Based on the transnationalists' suggestions and on the apparent intensification of trans-national activity among the EU member states, one would expect the EU to further integrate rather than to disintegrate. However, the refugee crisis revealed the common EU values are ranked differently from one EU member state to another. While some member states welcome and provide shelter to the refugees, others refuse to accommodate any of them. They even build 'walls' around their land borders to keep the refugees away. Whether this incompatibility of values will affect the process of European integration, it remains to be seen.

\section{Halfway Integration}

Etzioni views the process of EU integration through the Communitarianism's perspective (2001). He foresees successful political unification among the EU member states to be unattainable when the legal control armed force is not at the supranational level, when the member states do not benefit from the supranational allocation of resources, and when citizens' loyalties towards the supranational authorities do not take precedence over those towards the member states (Etzioni 2001, p. xxvvi). He also observes a 'halfway integration' in policy areas of 'shared' competences between the 
EU and the member states (Etzioni 2001, p. xxvvi). Such an area of 'shared' competences is the migration policy of the EU. Perhaps a 'fully integrated' EU would be able to tackle the refugee crisis more effectively than the current 'halfway integrated' EU and added to that, Brexit would not have occurred.

\section{Beneficial Membership}

Through another angle, Institutionalism focuses on the benefits that the states derive from their participation in the institutions. International Relations Institutionalism accepts states as the principal actors in European politics and suggests that organisations such as the EU can achieve a high level of durability by helping states to overcome collective action problems, carrying out functions that they cannot undertake by themselves, monitoring compliance, reducing uncertainty and stabilizing expectations (Keohane, 1993, pp. 274, 284, 288). Keohane highlights the important role that the hegemonic dominance and the convergence of the interests of the member states play for the durability of the institutions (1993, p. 295). Currently, some EU member states consider the refugees' arrivals beneficial for their economies and societies. Some other member states view them as economic and cultural threats. The extent to which this variation of views and interests of the EU member states will affect the 'durability' of the EU is hard to predict. The examination of the effects of the refugee crisis on the EU's 'durability' though, should always consider that European integration is a path-dependent process. Basic institutional structures, rules and policies are, once established, difficult to abolish or even to overhaul (Faber and Wessels, 2005, p. 8).

\section{Integration Theories Reversed}

Combining elements of each analytical framework would be suitable for explaining the current situation of the EU's (dis)integration. If these elements were combined with Webber's definition of disintegration, then the precise position of the EU on the integration-disintegration axis could be estimated. Webber describes EU disintegration as a decline in: 1) the range of common or joint policies adopted and implemented in the EU; 2) the number of EU member states; and/or 3) the formal and actual capacity of the EU organs to make and implement decisions if necessary against the will of individual members $(2014$, p. 342). The effort of scholars to theorise (dis)integration, as well as the application of these theories on the (dis)integration of the EU, are summarised in Figure 2.

\section{Refugee Crisis and Brexit}

Through a referendum on 23 June 2016, the majority of British voters supported Brexit. $^{6}$ To get to that point, the UK took advantage of the possibility of 'leaving' the EU provided to all EU member states by the latest amendment to the last of the EU Treaties. ${ }^{7}$ Immigration held a prominent place in the pre-Brexit discussions but was

\footnotetext{
${ }^{6}$ The amalgamation of the words Britain and exit results in the word Brexit. It describes the 'leave' of the UK from the EU.

${ }^{7}$ Article 50 provides that: "1. Any Member State may decide to withdraw from the Union in accordance with its own constitutional requirements. 2. A Member State which decides to withdraw shall notify the European Council of its intention. In the light of the guidelines provided by the European Council, the Union shall negotiate and conclude an agreement with that State, setting out the arrangements for its withdrawal, taking account of the framework for its future relationship with the Union. That agreement shall be negotiated in accordance with Article 218(3) of the Treaty on the Functioning of the European Union. It shall be concluded on behalf of the
} 
not the only factor that triggered Brexit. A variety of issues such as employment rights, trade agreements, taxation autonomy, and diplomatic influence were identified as motivating the UK to 'leave' the EU. However, the debate prior to the referendum was explicitly focused on one concern: immigration (Somerville 2016; Wilkinson, 2016).

Table 2. Theories of EU (dis)integration

\begin{tabular}{|c|c|c|}
\hline Theory & $\begin{array}{l}\text { Main Assumptions } \\
\end{array}$ & $\begin{array}{l}\text { Prognosis } \\
\end{array}$ \\
\hline Neo-Realism & $\begin{array}{l}\text { The world is made of states. Short life-expectancy of } \\
\text { international organisations }\end{array}$ & $\begin{array}{l}\text { The end of Cold War would result in a } \\
\text { multipolar Europe that would be } \\
\text { imbalanced and unstable }\end{array}$ \\
\hline Federalism & $\begin{array}{l}\text { A federation would not be able to survive for a long time } \\
\text { without: } \\
\text { - centralisation of tax \& armies } \\
\text { - guarantees for the partial autonomy of the constituent } \\
\text { units } \\
\text { - the federal loyalty of citizens } \\
\text { - cross-level political organised parties } \\
\text { - political-ideological commitment }\end{array}$ & $\begin{array}{l}\text { The EU lacks supranational army and } \\
\text { central taxation as well as the federal } \\
\text { loyalty of its citizens. As such, its } \\
\text { further integration towards an EU } \\
\text { federation is compromised. }\end{array}$ \\
\hline $\begin{array}{l}\text { Classical- } \\
\text { Intergovernm } \\
\text { entalism }\end{array}$ & $\begin{array}{l}\text { - Convergence of the preferences of interests of key } \\
\text { member states } \\
\text { - Requirements of domestic politics } \\
\text { are essential for the integration project }\end{array}$ & $\begin{array}{l}\text { Lack of convergences of the Franco- } \\
\text { German interests and } \\
\text { Euroscepticism lead to EU } \\
\text { disintegration }\end{array}$ \\
\hline $\begin{array}{l}\text { Neo- } \\
\text { Functionalis } \\
\text { m }\end{array}$ & $\begin{array}{l}\text { - Realisation of mutual gains from cooperation in } \\
\text { policy areas with high levels of functional } \\
\text { interdependence } \\
\text { - Spill-back -as the opposite of spillover- is possible to } \\
\text { occur }\end{array}$ & $\begin{array}{l}\text { Spill-back would be liable for } \\
\text { withdrawal from obligations, } \\
\text { disobedience to rules, and } \\
\text { decrease of scope of action and } \\
\text { institutional capacities }\end{array}$ \\
\hline $\begin{array}{l}\text { Transactional } \\
\text { ism }\end{array}$ & $\begin{array}{l}\text { The intensity of } \\
\text { - } \quad \text { transactions, communications, social exchange } \\
\text { - } \quad \text { compatibility of values } \\
\text { - } \quad \text { the commonality in identity and loyalty } \\
\text { - } \quad \text { joint rewards } \\
\text { may be utilised as indicators for assessing the potential } \\
\text { of deeper integration }\end{array}$ & $\begin{array}{l}\text { The lower the intensity of the } \\
\text { transactions the higher the pressures } \\
\text { for disintegration }\end{array}$ \\
\hline $\begin{array}{l}\text { Communitari } \\
\text { anism }\end{array}$ & 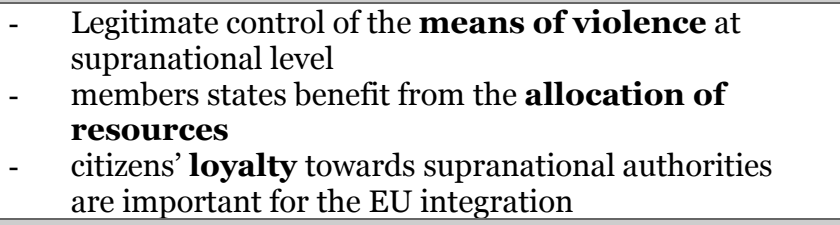 & $\begin{array}{l}\text { EU is a "halfway integration" and } \\
\text { as such instability in the process of } \\
\text { EU integration could be expected }\end{array}$ \\
\hline $\begin{array}{l}\text { International- } \\
\text { Relations } \\
\text { Institutionalis } \\
\quad \text { m }\end{array}$ & $\begin{array}{ll} & \text { Incentives for deeper integration are created when an } \\
\text { International Organisation } \\
\text { - } \\
\text { assists member states to overcome collective action } \\
\text { problems } \\
\text { - } \quad \text { carries out functions the member states cannot } \\
\text { - } \quad \text { monitors compliance } \\
\text { - } \quad \text { reduces uncertainty } \\
\text { stabilises expectations }\end{array}$ & $\begin{array}{l}\text { So far, the EU fulfils all the criteria } \\
\text { of IR Institutionalism for deeper } \\
\text { integration. Once it will cease } \\
\text { assisting member states overcoming } \\
\text { these difficulties, obstacles to the } \\
\text { EU's further integration will appear. }\end{array}$ \\
\hline
\end{tabular}

Source: Author's own compilation of (dis)integration theories.

\footnotetext{
Union by the Council, acting by a qualified majority, after obtaining the consent of the European Parliament. 3 . The Treaties shall cease to apply to the State in question from the date of entry into force of the withdrawal agreement or, failing that, two years after the notification referred to in paragraph 2, unless the European Council, in agreement with the Member State concerned, unanimously decides to extend this period. 4. For the purposes of paragraphs 2 and 3, the member of the European Council or of the Council representing the withdrawing Member State shall not participate in the discussions of the European Council or Council or in decisions concerning it. A qualified majority shall be defined in accordance with Article 238(3) (b) of the Treaty on the Functioning of the European Union. 5. If a State which has withdrawn from the Union asks to rejoin, its request shall be subject to the procedure referred to in Article 49.
} 
The British public's unease about immigration became apparent after the 2004 accession of Central and Eastern European states to the EU also caused the increase of migrants arriving in the UK. From 2015 onwards, such concerns were sharpened by the outbreak of the refugee crisis (Goodwin and Milazzo, 2017, p. 455). Various 'leave' campaigns dedicated attention and resources to intensify public concern on the immigration and refugee crisis. The claim made was that immigration exerted pressure on public services and that the refugee crisis led the EU to a 'breaking point' (Goodwin and Milazzo, 2017, p. 455). Several influential politicians followed a similar line of argumentation.

\section{World Leaders on the Brexit-Refugee Crisis Nexus}

Donald Tusk, the President of the European Council, repeatedly warned that the refugee crisis could trigger the withdrawal of the UK from the EU (Holehouse, 2016). Tusk considered the "chaotic influx of hundreds of thousands of refugees" to be "the greatest tool for Eurosceptics" (Holehouse, 2016). Equally, US President Donald Trump, directly blamed the EU refugee crisis for Brexit (Robins-Early, 2017). In line with his anti-immigration rhetoric, Trump argued that "people do not want to have other people coming in and destroying their country" and identified the refugee crisis as the primary reason for Britain backing 'leave' in the referendum (Robins-Early, 2017). Viktor Orbán, the Prime Minister of Hungary and another politician who openly expressed his aversion towards the refugees, justified Brexit on the inability of the EU to handle the refugee crisis (Crisp, 2016). Sebastian Kurz, the Chancellor of Austria, argued that the refugee crisis was 'decisive' for Brexit and predicted that it would break the EU apart (Hamed, 2016). He also portrayed the refugee crisis as an 'emotional issue' for the European people and alleged that "the unlimited acceptance [of refugees] and incompetence of the EU [shake] the foundations of the EU” (Hamed, 2016).

\section{Britons' Unease with the Refugee Crisis}

Prior to the referendum, immigration dominated the attention and coverage of the British media. Some of those, attempted to intensify the worries and confusion of the public over immigration. They managed to do so by mixing different issues under the same generalised and often intentionally inflammatory language (Devine, 2015). Right-wing British newspapers had for long carried incendiary stories about refugees. They focused on rare cases of asylum seekers getting more benefits and housing facilitations than the locally born citizens (Hall, 2016). Some months before the referendum, the front page of The Sun, one of the tabloids with the highest readership in the UK, compared immigration with the advance of enemy forces during WWII (Wilkinson, 2016). Another newspaper, the Daily Mail, was published on April 2016 headlining "Mass migration is allowing terrorists to pour into Europe" (Slack, 2016). The Sun during the same period claimed that "[...] Jihadis ARE exploiting refugee crisis to smuggle militants across Europe" (Cole, 2016). Since these tabloids enjoyed very high readership, it should not come as a surprise that they contributed, with their 'antiimmigration' and 'anti-refugee' headlines, to steering the voter's opinion towards Brexit.

In Spring 2016 found 70\% of Britons disapproving how the EU dealt with the refugee crisis (Pew Research Centre, 2016). They also considered their country's EU membership as responsible for the refugess' arrivals to the UK (Brinded, 2015). Britons were not always negative towards refugees however. Prior to the 2015 Paris terrorist 
attacks, British citizens empathised with the refugees escaping from the war in Syria. After these attacks British feelings towards refugees began to change. In December $2015,44 \%$ of Britons agreed with the decision of the UK to close its borders to refugees (Hall, 2016). Immigration remained a major issue for British voters which should not come as a surprise considering that the arguments made by the 'leave' advocates centred on immigration and national autonomy (Arnorsson and Zoega, 2016). In spring 2016, British citizens by $52 \%$ considered that refugees would increase the likelihood of terrorism in the UK and viewed the large number of refugees leaving Syria and Iraq as a major threat to the UK (Pew Research Centre, 2016). In April of the same year, $47 \%$ of British citizens rated immigration as the most pressing concern (Somerville, 2016). That was less than the $56 \%$ of British who viewed immigration as the most important issue faced by the UK in November 2015 (Devine, 2015). One month before the referendum, 51\%, considered migration as the most important problem of the EU (Standard Eurobarometer (EC), 2016, p. 7). Nearly 75\% of prospective referendum-voters in favour of Brexit considered immigration as the most pressing issue (Hall, 2016; Goodwin and Milazzo, 2017). The refugee crisis so often muddled and intertwined with the immigration crisis.

\section{Intra-EU Immigration and Brexit}

Recent academic research on the Brexit referendum points to the importance of immigration as a key driver of the result (Goodwin and Milazzo, 2017, p. 450). 'Sovereignty' and 'immigration' were the two most frequently cited concerns among those who voted in favour of Brexit (Evans et al, no date). The concerns of the public over immigration were also central to explaining why Britons voted to 'leave' the EU (Goodwin and Milazzo, 2017, p. 451) and contributed to the elevation of Euroscepticism within the UK. Since the 2004 'big bang' EU enlargement, Euroscepticism has intensified as the EU became gradually associated with the unpopular immigration from Eastern Europe (Evans et al, no date). That large influx of migrants 'fed' the belief that the UK no longer had control over its borders (Evans et $a l$, no date). It was also believed that the intra-EU immigration created greater 'stress' on schools, hospitals and housing (Frum, 2016) and generated student visa and welfare system abuses (Melus, 2016, p. 617).

Prior to the referendum, public hostility toward immigration was a major predictor of support for Nigel Farage's populist right wing United Kingdom Independence Party (UKIP) (Goodwin and Milazzo, 2017, p. 451). In 2010, when Cameron promised to reduce net migration to the UK to less than 100,000 people per year (Goodwin and Milazzo, 2017, pp. 455-456; Sevcikova, 2016, p. 965) he did not foresee that immigration would be used by UKIP to assume a prominent role in the Brexit referendum (Goodwin and Milazzo, 2017, p. 451) and to exaggerate fear of immigration in public debate that may have directed Britons to vote for Brexit (Arnorsson and Zoega, 2016, p. 22).

Most of the surveys and scholarly research indicate that it was not the fear about the UK being 'flooded' by refugees that triggered Brexit but the unease with the intra-EU immigration that motivated Britons to vote for 'leave'. It is noteworthy that of the 630,000 foreign nationals who settled in Britain since 2015, the overwhelming majority are EU citizens, exercising their right to free movement within the European Union (Rienzo and Vargas-Silva, 2017). Thus, considering the broad meaning that the word 'immigration' has for the British voters, following the Donald Trump line of 
argumentation, and that of Viktor Orbán and Sebastian Kurz and blaming Brexit on the refugee crisis and the 'open-borders' EU policy would be erroneous. Although Brexit constitutes a sign of EU's disintegration, it is not the only one. The disinclination of certain EU member states to abide by their obligations under the EU Treaties could also be perceived as a symptom of the EU's disintegration.

\section{The lack of Solidarity and the failure of the Relocation Scheme}

Some (dis)integration analytical frameworks consider the member states' noncompliance with the EU's supranational rules as a 'symptom' of the EU's disintegration. Given that just a few of the EU member states fulfilled their obligations under the relocation scheme, one could argue that the EU begun to integrate. What exactly happened with the relocation scheme? The relocation scheme is based on two Council Decisions (Council Decision (EU) 2015/1523; Council Decision (EU) 2015/1601) that provided for the distribution and relocation of initially 160,000 Syrian, Iraqi and Eritrean asylum applicants from Italy and Greece to the rest of Europe. The legal basis of this agreement can be found in the Lisbon Treaty. Based on the principle of solidarity and fair sharing of responsibility between the member states, the Lisbon Treaty stipulates the adoption of emergency measures for the benefit of EU member states confronted with a sudden inflow of third-country nationals (Treaty of Lisbon, 2007, Art. 78 and Art. 80). By the time of their announcement, Decisions of the EU should be binding in their entirety upon those to whom they are addressed. It should be expected therefore that the EU member states would be legally obliged to put into effect the Council's Decisions.

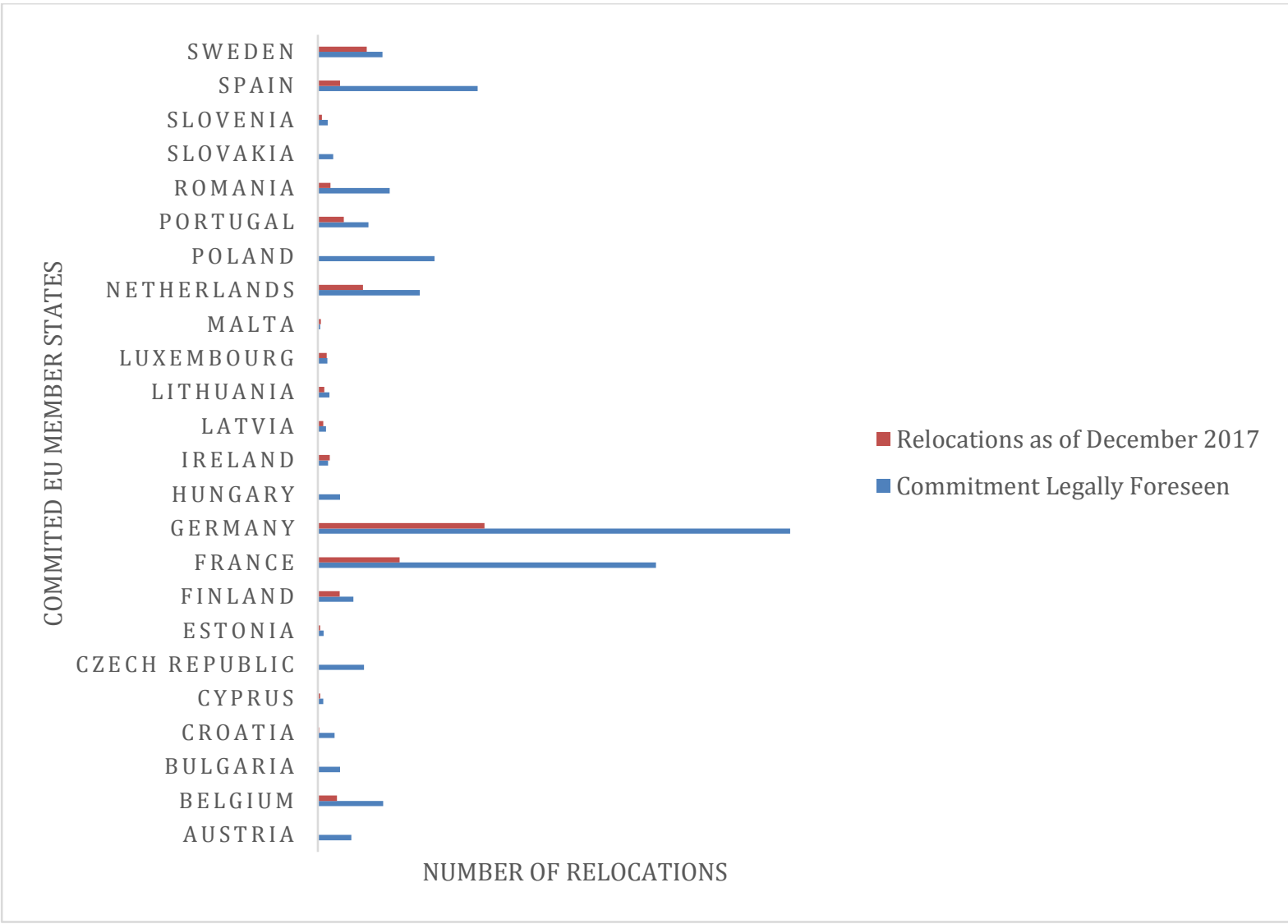

Source: European Commission (December 2017).

Figure 3. EU member states' Support to Emergency Relocation Scheme as of December 2017 
Nevertheless, two years after the adoption of these Decisions, the EU member states have fulfilled less than a third of their asylum relocation obligations (Amnesty International, 2017). As shown in Figure 3, most of the countries received only a small number of the prescribed asylum seekers. Poland and Hungary refused to accept any asylum seeker from Italy or Greece (Amnesty International, 2017). Slovakia has only accepted 16 of the 902 asylum-seekers it was assigned. The Czech Republic only 12 out of 2,691 . Spain has fulfilled just $13.7 \%$ of its quota, while Belgium just $25.6 \%$. The Netherlands has fulfilled $39.6 \%$ of the target it committed to, and Portugal $49.1 \%$ (Amnesty International, 2017). This is of course not the first time that member states have not fulfilled their obligations under the Treaties. However, it is one of the first times that they collectively disregard fundamental obligations and state in plain view their unwillingness to adjust their policies to the demands of the Council and the CJEU.

\section{Hungary, Slovakia and the Relocation Scheme}

As early as 2015 during the deliberations for the adoption of the EU relocation scheme it became apparent that its enforcement would be problematic. Four EU member states, Slovakia, Hungary, Czech Republic and Romania voted against accepting mandatory quotas. However, they were outvoted by all the other member states who backed the scheme in a qualified majority voting procedure. ${ }^{8}$ Immediately after the adoption of the Decisions, the Slovak Prime Minister, Robert Fico stated that he would not "respect the diktat of the majority" (BBC, 2015) and that "he [would] not implement [the mandatory quotas] on Slovak territory" (Robinson and Spiegel, 2015). "Whoever wants to divide Europe, let them put quotas on the table, who wants to unite Europe, let them come up with a different concept of the fight against illegal migration", Fico added (Lowe, 2016). He also turned openly against Muslims and claimed that "large Muslim communities" threatened Slovakia and Europe. He even argued that there was a direct link between the migration flows and the [November 2015's] attacks in Paris (Gabrizova, 2016).

Similar to their Slovak counterparts, the Hungarian political elites turned fiercely against the relocation scheme and the refugees. Hungary, a country that also faced a substantial inflow of migrants, as thousands of asylum seekers made their way through her territory, was initially supposed to benefit from the scheme and opted-out. The initial plan of the Commission provided for Hungary to redistribute 54,000 asylum seekers out of the 120,000 of the entire scheme. Hungary rejected the plan as jeopardizing the country's security by turning it into a huge refugee camp (Robinson and Spiegel, 2016). That rejection was 'in line' with the 'anti-immigration' rhetoric of the Hungarian Prime Minister, Viktor Orbán, who openly claimed that asylum seekers posed a serious threat to his country and the EU (Dallison, 2015). Orbán presented the relocation scheme as "an act of out-of-touch Brussels bureaucrats usurping national authority" and warned that the migration crisis could drive more countries out of the EU (Szakacks, 2016). According to him, there were political, economic and intellectual leaders in Europe who tried to transform Europe in opposition to the European people. He reckoned that the EU could fall apart because it was divided into two camps: the "unionists", who believed in the 'United States of Europe' and the relocation quotas, and the "sovereignists" who saw Europe as a coalition of free nations (Zalan, 2016). The last straw for Orbán was the referendum on the quota system. The "quota

\footnotetext{
${ }^{8}$ It is noteworthy that Finland abstained from the vote and Poland, which had originally opposed the proposal, in the end voted in favor.
} 
referendum' asked the Hungarians whether they desired the EU to be able to mandate the obligatory resettlement of non-Hungarian citizens into Hungary even without the approval of the National Assembly. Against Orbán's expectations and despite his furious campaigns, the vote on the referendum was not binding since the turnout was below the 50\% threshold needed (The Economist, 2016). Facing the threat of losing the referendum due to the low turnout, the government's campaign turned to xenophobic, and linked migrants to crime and terrorism (The Economist, 2016). The strong anti-refugee narrative of both the Slovak and Hungarian political elites indicated their determination to disobey the demands of the relocation scheme's mandatory quotas.

\section{The Relocation Scheme and the Court of Justice of the European Union (CJEU)}

Slovakia and Hungary not only rejected the relocation scheme but also challenged the application of the quotas before the CJEU. Slovakia first issued a lawsuit over the Council's Decision. Hungary followed and together they requested the Court to annul the scheme. The plaintiff states argued that the European Council failed to follow proper EU legislative procedures, according to which the consent of all the EU and sometimes national decision-making bodies should be obtained before the Council's Decisions acquire legally binding effects. They also challenged the Decision's suitability to respond to the migrant crisis effectively. ${ }^{9}$ The CJEU dismissed their actions in their entirety. Considering the urgency of the situation, the Court found that the scheme was justifiable as an emergency measure and rejected the argument that the burdensharing system was not appropriate for responding to the migration problem. It also affirmed the correctness of the legislative procedures followed.

With ruling of the CJEU against Hungary and Slovakia being so clear and unequivocal, there was an expectation that fines would be imposed if the quota system was ignored. Yet, the prospect of being heavily punished did not alter Orbán's and Fico's approach towards the scheme. Orbán, upon hearing of the Court's ruling, announced that the "real battle [was] just beginning", and vowed to continue his fight against the relocation scheme (Al Jazeera, 2017). He accepted however that "the bloc's treaties [should] be respected and the Court's rulings [should] be acknowledged" (Al Jazeera, 2017). To complicate things even more, he interpreted the ruling as requiring Hungary to do nothing (Al Jazeera, 2017). Similarly, the Slovak officials emphasised that they would comply with the ruling but also underlined that their position remained against the relocation plan (Deutsche Welle, 2017). Fico stated that the "[Slovak] position on quotas does not change" and added that "[Slovakia] will continue to work on having solidarity expressed in different ways other than forcing [on her] migrants from other countries that don't want to be [there] anyway" (Deutsche Welle, 2017). The responses of Slovakia and Hungary to the judgement of the CJEU demonstrate their determination to remain firm in their positions. Although they declared they would abide by the Court's ruling, as the contested Decision ${ }^{10}$ ended in September 2017 neither Hungary nor Slovakia have received any more asylum seekers. It is very likely

\footnotetext{
${ }^{9}$ Slovakia and Hungary v. Council, C-643/15 and C-647/15 (Court of Justice of the European Union, September 6, 2017).

${ }^{10}$ The Council's Decision and the mandatory relocation scheme expired two years after their enforcement, at the end of September 2017.
} 
that in the near future the Commission will challenge them anew before the CJEU alongside other member states also not fulfilling their obligations under the scheme. ${ }^{11}$

\section{The Fiasco of the Relocation Scheme: A Warning of the EU's Disintegration?}

Could the disobedience of the EU member states towards a legally binding act of the EU be interpreted as contributing to the EU's disintegration because of a demonstrated lack of commitment to 'Brussels-made' rules? The inability of the EU to implement the scheme reveals the difficulty of achieving consensus' in matters that involve the concession of national sovereignty and manifests that there is a long way to go till the EU member states to decide to unanimusly confer powers to the EU to deal with sensitive issues such as the control of who, how, and why enters their territory, the number and manner of 'infiltration' by third-country nationals, and the control of the 'means of violence'. This is not the first time that the EU member states have not achieved consensus in sovereignty-related matters. Even though the Commission and/or the CJEU penalise certain member states for not complying with EU rules, if Hungary and Slovakia keep on not fulfilling their obligations under the Treaties and if more EU member states imitate this behaviour, then we will most likely deal with the beginning of the disintegration of the EU. Yet, apart from generating symptoms of EU disintegration the refugee crisis seems to have produced developments of deeper integration too.

\section{Double Standards}

Fico and Orbán's hostility towards the scheme exposes their 'unease' with the EU deciding matters directly related to their country's sovereignty and their exclusive right to decide who enters and who leaves their countries' territories. Migration and asylum policies are such sovereignty related matters. Surprisingly, just a few months after they rejected the relocation scheme, Fico and Orbán did not hesitate to support the proposal for the establishment of the European Border and Coast Guard Regulation (EBCG) which made the intervention of an EU agency in any EU member state's sovereign waters possible even without the consent of the member state(s) concerned (Gabrizova, 2016). It seems, therefore, that the 'rebellious' member states apply double standards when faced with loss of sovereignty to the European Union. Whilst Slovakia and Hungary vigorously resisted the mandatory relocation scheme because of its relation to sensitive sovereignty matters, the very same member states did not hesitate to vote in favour of the EBCG Regulation that permits an EU agency to intervene in the territorial waters of a member state affected by migration without their consent. If one considers that Slovakia and Hungary are not surrounded by water, their approach becomes understandable.. Due to their geographical position, they will never have to accept the intervention of the EBCG in their territory without consent.

Surely, both the EU relocation scheme and the EBCG are designed for countering the effects of the refugee crisis. Yet, while the first reveals signs of disintegration of the EU, the second is a clear manifestation of deeper integration. The conferral of more powers to the EU by its member states is considered a sign of deeper integration by most

\footnotetext{
${ }^{11}$ Already from last June (2017) the EU Commission launched legal proceedings against the Czech Republic, Hungary and Poland for not implementing the relocation scheme.
} 
analytical frameworks assessing the phenomenon of the EU's integration. The refugee crisis seems to simultaneously produce negative as well as positive developments. However, at the moment, its negative repercussions seem to surpass the positive. As the establishment of the EBCG is regarded as a mere 'update' of Frontex, it will take more 'integrative measures' to suggest that the refugee crisis 'unites' rather than 'divides' the EU.

\section{Conclusions}

This study has assessed the extent to which the EU refugee crisis relates to two of the latest symptoms of the EU's disintegration: Brexit and the failure of the EU's relocation scheme. The findings suggest that, indeed, the departure of a member state from the EU constitutes a strong manifestation of the EU's disintegration. Yet, as the analysis of the data reveals, it was the fear about the intra-EU migration that triggered the British voters to vote in favour of Brexit. The refugee crisis' contribution to Brexit was minimal. It was merely utilised by politicians and the mass media to intensify the fears of the Britons about migration. It is therefore hard for a link between the refugee crisis and Brexit to be established. It is also difficult to suggest that Brexit will be detrimental to the process of the EU's integration in the medium and long term. Throughout its EU membership, the UK continuously espoused a trade-based, laissez-faire, intergovernmental, broad-and-shallow vision of the EU (Evans et al, no date) and opted out from major EU projects. The Schengen agreement, the Euro currency, the Area of Freedom Security and Justice and the EU Charter of Fundamental Rights are some of these projects. These opt-outs were indications of Britain's weaker sense of European identity (Evans et al, no date). Certainly, following Brexit, the EU will lose one of her three largest member states. However, without one of her core member states abstaining from all her major projects of deeper integration, the EU will most likely manage to integrate further than before.

As for the EU relocation scheme, it would appear that the refugee crisis brought to the fore the EU member states' inclination to prioritise the facilitation of their own interests over the promotion of the EU's common good. It has also made clear the double standards that some EU member states apply in sovereignty-related matters. Considering the noncompliance of the EU member states with the relocation scheme and the relatively uncomplicated adoption of the EBCG Regulation, one could argue that, simultaneously, the refugee crisis stimulates the disintegration and the further integration of the EU. Any type of crises has a starting and an end point in time. The EU refugee crisis is still ongoing. Whether the end of the EU refugee crisis will find the EU deeper integrated or further disintegrated, remains to be seen.

\section{Bibliography}

Al Jazeera, 'Hungary to fight EU migrant quotas despite setback', Al Jazeera, 9 September 2017, http://www.aljazeera.com/news/2017/09/hungary-fight-eumigrant-quotas-setback-170908153009948.html, accessed on 12th of December 2017.

Amnesty International, 'Countries have fulfilled less than a third of their asylum relocation promises', Amnesty International, 25 September 2017, https://www.amnesty.org/en/latest/news/2017/o9/eu-countries-have-fulfilled-less-than-a-thirdof-their-asylum-relocation-promises/, accessed on 12th of December 2017. 
Arnorsson, A. and Zoega, G., 'On the Causes of Brexit', CESifo Working Paper Series No. 6056, 23 August 2016, https://ssrn.com/abstract=2851396, accessed on 12th of December 2017.

Bartolini, S., Restructuring Europe: centre formation, system building and political structuring between the nation state and the European Union. Oxford: Oxford University Press, 2007.

BBC, 'Migrant Crisis: Opponents Furious over new EU Quotas', BBC, 22 September 2015, http://www.bbc.com/news/world-europe-34331126, accessed on 12th of December 2017.

Brinded, L., 'The Refugee Crisis is Killing Britain's Chances of Staying within the EU', Business Insider UK, 19 October 2015, http://uk.businessinsider.com/hsbc-researchrefugee-crisis-could-cause-an-eu-referendum-brexit-2015-10, accessed on 12th of December 2017.

Bosoni, A., 'Who will exit the EU next?' Stratfor, 4 October 2016, https://worldview.stratfor.com/article/who-will-exit-eu-next, accessed on 12th of December 2017.

Cole, H., 'Tide of Terror: Jihadis ARE exploiting refugee crisis to smuggle militants across Europe', The Sun, 5 April 2016, https://www.thesun.co.uk/archives/politics/1115859/tide-of-terror-jihadis-areexploiting-refugee-crisis-to-smuggle-militants-across-europe-the-eus-own-borderagency-sensationally-admits/, accessed on 12th of December 2017.

Consolidated Version of the Treaty on the Function of the European Union (TFEU), 13 December 2007, 2008/C 115/o1.

Council Decision (EU) 2015/1523 of 14 September 2015 establishing provisional measures in the area of international protection for the benefit of Italy and of Greece, OJ L 239/146; Council Decision (EU) 2015/1601 of 22 September 2015 establishing provisional measures in the area of international protection for the benefit of Italy and of Greece, OJ L 248/80.

Crisp, J., 'Refugee Crisis and EU Migration Policy to Blame for Brexit says Hungary's Orbán', EURACTIV, 29 June 2016, https://www.euractiv.com/section/ukeurope/news/refugee-crisis-and-eu-migration-policy-to-blame-for-brexit-sayshungarys-orban/, accessed on 12th of December 2017.

Court of Justice of the European Union, Slovakia and Hungary v. Council, C-643/15 and C-647/15, September 6, 2017.

David, E. J., 'Brexit wound: UK vote makes EU decline 'practically irreversible', Soros says', CNBC, 25 June 2016, https://www.cnbc.com/2016/o6/25/brexit-makes-eusdissolution-practically-inevitable-george-soros.html, accessed on 12th of December 2017.

Dallison, P., 'Hungary Second to Challenge EU's Refugee Scheme', Politico, 3 December 2015, https://www.politico.eu/article/hungary-second-to-challenge-eusrefugee-scheme/, accessed on 12th of December 2017. 
Deutsch, K. W., Political community and the North Atlantic area; international organisation in the light of historical experience, New York: Greenwood Press, 1969.

Deutsche Welle 'Refugee crisis: European Court of Justice rejects quota challenge', Deutsche Welle, 6 September 2017, (http://www.dw.com/en/refugee-crisiseuropean-court-of-justice-rejects-quota-challenge/a-40375192)

Devine, L., 'Refugees', 'migrants' and the Brexit vote', The Law Society Gazette, 16 November 2015, https://www.lawgazette.co.uk/legal-updates/refugees-migrantsand-the-brexit-vote/5052157.article, accessed on 12th of December 2017.

Etzioni, A., Political unification revisited: on building supranational communities, Lanham: Lexington Books, 2001.

European Commission, 'Member States' Support to Emergency Relocation Mechanism as of 7 December 2017', 7 December 2017, https://ec.europa.eu/homeaffairs/sites/homeaffairs/files/what-we-do/policies/european-agendamigration/press-material/docs/state_of_play___relocation_en.pdf, accessed on 12th of December 2017.

European Commission, 'Standard Eurobarometer', May 2016, http://ec.europa.eu/COMMFrontOffice/publicopinion/index.cfm/Survey/getSurveyDetail/instruments/STANDARD/surveyKy/213 o, accessed on 12th of December 2017.

European Commission, 'White Paper on the Future of Europe, Reflections and Scenarios for the EU27 by 2025', COM (2017) 2025, 1 March 2017, https://europa.eu/european-union/sites/europaeu/files/whitepaper_en.pdf, accessed on 12th of December 2017.

Evans, G., Noah C. and Dennison J. 'Europeans but not European Enough: The Causes and Consequences of Brexit', https://www.academia.edu/29503724/EUROPEAN_BUT_NOT_EUROPEAN_ENO UGH_-THE_CAUSES_AND_CONSEQUENCES_OF_BREXIT, accessed on 12th of December 2017.

Faber, A and Wessels W., 'Wider Europe, Deeper Integration? A common theoretical framework for EU-CONSENT', Paper for the Kick-off Meeting, November 18th, 2005, Brussels, http://www.eliamep.gr/wp-content/uploads/en/2008/10/faber_widening_deepening.pdf, accessed on 12th of December 2017.

Franck, M. T., Why federations fail: an inquiry into the requisites for successful federalism, New York: New York University Press 1968.

Frum, D., 'Why Britain Left', The Atlantic, 24 June 2016, https://www.theatlantic.com/international/archive-/2016/06/brexit-eu/488597/, accessed on 12th of December 2017.

Gabrizova, Z., 'Slovak PM: 'It's impossible to integrate Muslims', EURACTIVE, 6 January 2016, http://www.euractiv.com/section/central-europe/news/slovak-pm-its-impossible-to-integrate-muslims/, accessed on 12th of December 2017. 
Goodwin, M. and Milazzo C., 'Taking back Control? Investigating the Role of Immigration in the 2016 Vote for Brexit', The British Journal of Politics and International Relations, 2017, Vol. 19, No. 3, 2017, pp. 450-464.

Haas, B. E., Collective security and the future international system, Denver, CO: University of Colorado, 1968.

Hall, R., 'How the Brexit Campaign used Refugees to Scare Voters', Public Radio, 24 June 2016, https://www.-pri.org/stories/2016-06-24/how-brexit-campaign-usedrefugees-scare-voters, accessed on 12th of December 2017.

Hamed, M., 'Refugee Crisis 'Decisive' for Brexit, will break EU Apart- Austrian FM', Russia Today, 30 June 2016, https://www.rt.com/news/349055-refugee-crisisbrexit-austria/, accessed on 12th of December 2017.

Holehouse, M., 'Migrant Crisis could Trigger Brexit, fears EU's Tusk', The Telegraph, 10 February 2016, http://www.telegraph.co.uk/news/worldnews/europe/eu/12151092/Migrant-crisiscould-trigger-Brexit-fears-EUs-Tusk.html, accessed on 12th of December 2017.

Kelemen, R. D., 'Built to Last? The Durability of EU Federalism', in S. Meunier and K. McNamara (eds.), Making History: The State of the European Union, Oxford: Oxford University Press, 2007, pp. 51-66.

Keohane, O. R., 'Institutional theory and the realist challenge after the Cold War, in D. Baldwin (ed.), Neorealism and Neoliberalism: The Contemporary Debate, New York: Columbia University Press, 1993, pp. 269-300.

Lindberg, N. L. and Scheingold, S. Europe's would-be polity: Patterns of change in the European Community, New Jersey: Prentice-Hall, 1970.

Lowe, J., 'Slovakian PM: Refugee Quotas are 'Finished', Newsweek, 28 September 2016, http://www.-newsweek.com/eu-refugees-robert-fico-viktor-orban-quotasrefugee-crisis-relocation-503601, accessed on 12th of December 2017.

Mearsheimer, J. J., 'Back to the Future: Instability in Europe after the Cold War. International Security, Vol. 15, No. 1, 1990, pp. 5-56.

Melus, M., 'The Reasons of Possible "Brexit” from the European Union' in E. Kovarova, L. Melecky and M. Stanickova (eds.), Proceedings of the 3rd International Conference on European Integration 2016, Ostrava: VSB - Technical University of Ostrava, 2016, pp. 615-622.

Poushter, J. 'European Opinions of the Refugee Crisis in 5 Charts', Pew Research Centre, 16 September 2016, http://www.pewresearch.org/fact-

tank/2016/o9/16/european-opinions-of-the-refugee-crisis-in-5-charts/, accessed on 12 th of December 2017.

Rienzo, C., and Vargas-Silva C.,, 'Migrants in the UK. An Overview', The Migration Observatory, 21 February 2017, http://www.migrationobservatory.ox.ac.uk/wpcontent/uploads/2017/O2/Briefing-Migrants_UK_Overview.pdf, accessed on 12th of December 2017. 
Riker, W., 'Federalism' in F. Greenstein and N. Polsby (eds.), The Handbook of Political Science, Government Institutions and Processes, Reading, MA: AddisonWesley, 1975, pp. 93-172.

Robins-Early, N., 'Donald Trump says Refugee Crisis and Threats to UK Identity Drove Brexit', Huffington Post, 15 January 2017, https://www.huffingtonpost.com/entry/trump-brexit-refugees_us_587bf562e4b09281doeb8oda, accessed on 12 th of December 2017.

Robinson, D. and Spiegel P., 'EU Ministers force through refugee quota plan', Financial Times, 23 September 2015, https://www.ft.com/content/76c2dd9e-611111e5-9846-de406ccb37f2, accessed on 12th of December 2017.

Sandholtz, W. and Stone Sweet A., 'Integration, Supranational Governance, and the Institutionalization of the European Polity' in W. Sandholtz and A. Stone Sweet (eds.), European Integration and Supranational Governance. Oxford: Oxford University Press, 1998.

Schmitter, C. P. and Lefkofridi Z., 'Neo-functionalism as a Theory of Disintegration', Chinese Political Science Review, No. 1, 2016, pp. 1-29.

Schmitter, C. P., How to democratise the European Union ... and why bother? Lanham: Rowman \& Littlefield, 2000.

Sevcikova, M., 'Analysis of the Main Causes of Brexit and Its Potential Consequences' in E. Kovarova, L. Melecky and M. Stanickova (eds.), Proceedings of the 3rd International Conference on European Integration 2016, Ostrava: VSB - Technical University of Ostrava, 2016, pp. 961-969.

Slack, J., 'Mass migration is allowing terrorists to pour into Europe', The Daily Mail, 6 April 2016, https://darkhorsenews.com/mass-migration-is-allowing-terrorists-topour-into-europe/, accessed on 12th of December 2017.

Slack, J., 'Staggering' number of European jihadis: EU's own border agency admits terrorists are exploiting refugee crisis and lax controls - but has no idea how many illegal immigrants there are', The Daily Mail, 5 April 2016, http://www.dailymail.co.uk/news/article-3525279/Mass-migration-allowingterrorists-pour-Europe-EU-s-border-agency-admits-s-revealed-false-documents-notfacing-thorough-checks.html, accessed on 12th of December 2017.

Somerville, W., 'Brexit: the Role of Migration in the Upcoming EU referendum', Migration Policy Institute, 4 May 2016, https://www.migrationpolicy.org/article/brexit-role-migration-upcoming-eureferendum, accessed on 12th of December 2017.

Stokes, B., 'Euroskepticism beyond Brexit. Significant opposition in key European Countries to an ever Closer EU', Pew Research Center, 7 June 2016, http://www.pewglobal.org/files/2016/o6/Pew-Research-Center-Brexit-ReportFINAL-June-7-2016.pdf, accessed on 12th of December 2017.

Szakacks, G., 'Hungary’s Migrant Referendum Shows Europe’s post-Brexit Challenge', Reuters, 1 July 2016, https://www.reuters.com/article/us-britain-eu- 
hungary-orban/hungarys-migrant-referendum-shows-europes-post-brexitchallenge-idUSKCNoZH54H, accessed on 12th of December 2017.

The Economist, 'Viktor Orban fails to win his referendum against migrants', The Economist, 3 October 2016, https://www.economist.com/news/europe/21708083anti-refugee-publicity-ploy-falls-far-short-needed-turnout-viktor-orban-fails-winhis, accessed on 12th of December 2017.

Tilford, S., 'Britain, immigration and Brexit', (Issue brief No. 105), Centre for European Reform, 2016, http://www.cer.eu/sites/default/files/bulletin_105_st_article1.pdf, accessed on 12th of December 2017.

Vollaard, H., 'A Theory of European Disintegration', Paper Presented at the Fourth Pan-European Conference on EU Politics, 25th - 27th September 2008, University of Latvia, Riga.

Warren, J., 'Professor who predicted Brexit and Trump claims European Union will CEASE TO EXIST in 2017', Express, 4 January 2017, https://www.express.co.uk/news/uk/750018/European-Union-Brexit-Trump-predication-collapse, accessed on 12th of December 2017.

Webber, D., 'How likely is that the European Union will disintegrate? A critical analysis of competing theoretical perspectives', European Journal of International Relations, Vol. 20, No. 2, 2014, pp. 341-365.

Wilkinson, A., 'The Brexit Vote is really about Just One Thing', New Republic, 22 June 2016, https://newrepublic.com/article/134507/brexit-vote-really-just-onething, accessed on 12th of December 2017.

Zalan, E., 'Orban: EU Leaders Lack Will to Stop Migrants', EUobserver, 29 February 2016, https://euobserver.com/migration/132492, accessed on 12th of December 2017. 